OPEN ACCESS

Edited by:

Qiang Wang,

Institute of Hydrobiology (CAS), China

Reviewed by:

Zhenmei Lu,

Zhejiang University, China

Yonghong $B i$

Institute of Hydrobiology (CAS), China

*Correspondence:

Zhen Tao

taozhen@nbu.edu.cn

Tianling Zheng

wshwzh@xmu.edu.cn

tThese authors have contributed equally to this work.

Specialty section:

This article was submitted to Microbiotechnology, Ecotoxicology and Bioremediation,

a section of the journal

Frontiers in Microbiology

Received: 23 February 2017

Accepted: 18 May 2017

Published: 06 June 2017

Citation:

Zhang $H$, Wang $H$, Zheng $W$, Yao $Z$,

Peng Y, Zhang S, Hu Z, Tao Z and

Zheng $T$ (2017) Toxic Effects

of Prodigiosin Secreted by Hahella sp.

KA22 on Harmful Alga Phaeocystis globosa. Front. Microbiol. 8:999. doi: 10.3389/fmicb.2017.00999

\section{Toxic Effects of Prodigiosin Secreted by Hahella sp. KA22 on Harmful Alga Phaeocystis globosa}

\author{
Huajun Zhang ${ }^{1+}$, Hui Wang ${ }^{2+}$, Wei Zheng ${ }^{3}$, Zhiyuan Yao', Yun Peng ${ }^{3}$, Su Zhang ${ }^{3}$, \\ Zhong $\mathrm{Hu}^{2}$, Zhen Tao ${ }^{1 *}$ and Tianling Zheng ${ }^{3 *}$

\begin{abstract}
${ }^{1}$ School of Marine Sciences, Ningbo University, Ningbo, China, ${ }^{2}$ Biology Department, College of Life Science, Shantou University, Shantou, China, ${ }^{3}$ State Key Laboratory of Marine Environmental Science and Key Laboratory of the Ministry of Education for Coastal and Wetland Ecosystems, School of Life Sciences, Xiamen University, Xiamen, China
\end{abstract}

Application of algicidal compounds secreted by bacteria is a promising and environmentally friendly strategy to control harmful algal blooms (HABs). Years ago prodigiosin was described as an efficient algicidal compound, but the details about the effect of prodigiosin on algal cells are still elusive. Prodigiosin shows high algicidal activity on Phaeocystis globosa, making it a potential algicide in HAB control. When P. globosa were treated with prodigiosin at $5 \mu \mathrm{g} / \mathrm{mL}$, algae cells showed cytoplasmic hypervacuolization, chloroplast and nucleus rupture, flagella missing, and cell fracture, when observed by scanning electron microscope and transmission electron microscopy. Prodigiosin induced a reactive oxygen species (ROS) burst in $P$. globosa at $2 \mathrm{~h}$, which could result in severe oxidative damage to algal cells. Chlorophyll a (Chl a) fluorescence decreased significantly after prodigiosin treatment; about 45.3 and $90.0 \%$ of algal cells lost $\mathrm{Chl}$ a fluorescence at 24 and $48 \mathrm{~h}$. The $F_{\mathrm{v}} / F_{\mathrm{m}}$ value, reflecting the status of the photosystem II electron flow also decreased after prodigiosin treatment. Quantitative polymerase chain reaction (PCR) analysis psbA and rbcS expression indicated that photosynthesis process was remarkably inhibited by prodigiosin. The results indicated that the inhibition of photosynthesis may produce excessive ROS causing cell necrosis. This study is the first report about algal lysis mechanism of prodigiosin on harmful algae. Our results could increase our knowledge on the interaction between algicidal compounds and harmful algae, which could lead to further studies in the microcosm.

Keywords: prodigiosin, Phaeocystis globosa, oxidative stress, photosynthesis inhibition, cell death

\section{INTRODUCTION}

Harmful algal blooms (HABs), as the most severe consequence of eutrophication, occur worldwide causing irreversible damage to fisheries, tourism, public health, and the ecosystem (Heisler et al., 2008). Phaeocystis (Prymnesiophyceae), an important widespread marine haptophyte, could lead to blooms with agminated colonies in marine ecosystem (Rousseau et al., 2007). HAB, caused by Phaeocystis globosa, are frequent blooms in coastal waters (Sheik et al., 2014), producing excessive foam when elimination, which would be a problem for socio-economic activities (Peperzak and Gäbler-Schwarz, 2012).

Continual HAB outbreaks in coastal waters had received the focus of scientists, promoting to develop innovative technologies and strategies to management it (Anderson et al., 2012). There are 
several strategies to control HABs, including the use of physical methods (i.e., clay) and chemical algicides (Li and Pan, 2013; Guo et al., 2015). In recent years, biological methods to control $\mathrm{HAB}$ have got special attention on account of their species specificity, effectiveness, and eco-friendly properties (Roth et al., 2008; Son et al., 2015). Interestingly, some bacteria are able to secrete metabolic compounds specifically killing harmful phytoplankton, suggesting that the algicide from bacteria might function as a harmful algae biological control agent in seawaters (Wang et al., 2010a). In the past, we had identified an effective algicidal compound, prodigiosin, from Hahella sp. KA22 that shows high algicidal activity against $P$. globosa (Zhang et al., 2016). Prodiginines (6-methoxyprodigiosenes) comprise of various pigmented tripyrrole antibiotics, with potential medical use as immunosuppressants and antitumor agents (Sang et al., 1998; Pérez-Tomás et al., 2003), that can also kill red tide Cochlodinium polykrikoides dinoflagellates (Jeong et al., 2005). It has been proved that prodigiosin possesses algicidal activity particularly on several specific dinoflagellates, including C. polykrikoides, Gyrodinium impudicum, and Heterosigma akashiwo, and also raphidophyte Chattonella sp. (Kim et al., 2008). Our previous study demonstrated that prodigiosin could lyse $P$. globosa cells at the concentration of $1 \mu \mathrm{g} / \mathrm{mL}$ (Zhang et al., 2016). Moreover, the prodigiosin was thermo-stable and light-degradable indicating that prodigiosin may be a potential algicide for controlling $\mathrm{HAB}$ in natural environments. However, the activity of prodigiosin has not been thoroughly examined and the algicidal mechanism on $P$. globosa remains elusive.

Current studies indicate that the algicidal mechanisms against $\mathrm{HAB}$ include mainly four pathways: cell structure destruction, photosynthesis inhibition, respiration impairment, and alteration of enzymatic activities (Choudhary et al., 2007; Affenzeller et al., 2009; Zhang et al., 2010). During the algicidal process, the algicidal compounds could induce various damage (i.e., oxidative) to algal cells, morphological alterations, and degradation of DNA or proteins that can result in cell death. Aquatic organisms, including algae, possess antioxidant defenses system to remove excessive reactive oxygen species (ROS) and thus prevent oxidative damage triggered by malondialdehyde (MDA). Catalase (CAT), superoxide dismutase (SOD), glutathione peroxide (GPx), glutathione reductase (GR), and micromolecular compounds including carotenoids and glutathione, constitute antioxidant defenses system (Kirilovsky, 2015; Sanchez et al., 2015). Therefore, study on the physiological response of algae to algicidal compounds may be helpful to understand their algicidal mechanisms.

Our previous study was mainly on the isolation and characterization of prodigiosin from Hahella sp. KA22 (deposited in China Center for Type Culture Collection; CCTCC M2014297). We demonstrated that prodigiosin could efficiently kill P. globosa (Zhang et al., 2016). The present study provides the first evidence about the algicidal mechanism of this pigment on $P$. globosa. With the purpose to explore the algicidal mechanism of prodigiosin, the present study were designed to (1) investigate the alteration of algal cell structure including membrane, nucleus and ultrastructure; (2) study the response of antioxidant system in algal cells; and (3) explore photosynthesis damage of algal cells.

\section{MATERIALS AND METHODS}

\section{Algal Culture Preparation and Prodigiosin Treatment}

Phaeocystis globosa culture was stored in the Algal Culture Collection (Jinan University), under the accession number PG03. Algae were incubated in sterile $\mathrm{f} / 2$ medium, and cultured at $20 \pm 1^{\circ} \mathrm{C}$ under a $12 \mathrm{~h}$ light:12 $\mathrm{h}$ dark cycle with a $50 \mu \mathrm{mol}$ photons $\mathrm{m}^{-2} \mathrm{~s}^{-1}$ light intensity (Zheng et al., 2012). Algal cells in the logarithmic growth phase $\left(10^{6}\right.$ cells $\left./ \mathrm{mL}\right)$ were prepared for all the following tests.

Prodigiosin dissolved in dimethylsulfoxide (DMSO) was added into $20 \mathrm{~mL}$ algal cultures to the final concentrations of 3 and $5 \mu \mathrm{g} / \mathrm{mL}$. Sampling was performed at 12, 24, 36, 48, and $72 \mathrm{~h}$, by centrifugation at $5,000 \times g$ for $5 \mathrm{~min}$. DMSO serving as control was also added into algal cultures with equal volume as prodigiosin.

\section{The Assays of ROS Changes, Malondialdehyde Content, and Antioxidative Enzyme Activities}

ROS accumulation was analyzed by the fluorescent probe, $2^{\prime}, 7^{\prime}$-dichlorofluorescin diacetate (DCFH-DA), referring to a previously reported method (Rastogi et al., 2010) with some changes: $0.5 \mathrm{~mL}$ DCFH-DA were added to the cells and the mixture at the final concentration of $10 \mu \mathrm{M}$, then the mixture was stored at $37^{\circ} \mathrm{C}$ with light avoidance for about $1 \mathrm{~h}$. Cells were then washed three times using sterile $\mathrm{f} / 2$ medium following stored in it. A spectrofluorometer was used to monitor the fluorescence intensity of the DCFH-DA with an excitation wavelength set at $485 \mathrm{~nm}$ and an emission wavelength at $525 \mathrm{~nm}$.

The antioxidant system was also analyzed by measuring SOD, CAT, GR, and GPx in P. globosa according to methods described previously (Zhang et al., 2013). Twenty milliliters of each culture including control and treatment group were collected to detect the alteration of the antioxidative enzymes. MDA, which is a by-product of lipid peroxidation, was analyzed at the same time.

\section{Analysis of the Algicidal Process by Electron Microscopy and Laser Scanning Confocal Microscope}

To analyze the morphological features of the algicidal process, algal cells were collected and observed by scanning electron microscope (SEM). Algal cells $(1 \mathrm{~mL})$ were first fixed with glutaraldehyde $(2.5 \%)$ and washed in phosphate buffered saline (PBS) solution (50 mM, pH 7.8); cells were then placed on cover slips and air-dried. After that, the slides were subjected to SEM (JSM6390, JEOL Co., Tokyo, Japan) analysis after dehydration. To analyze ultrastructural changes, algal cells were observed by a transmission electron microscope (TEM, JEM2100HC, JEOL Co., Tokyo, Japan) according to our previous study (Zhang et al., 2013). 

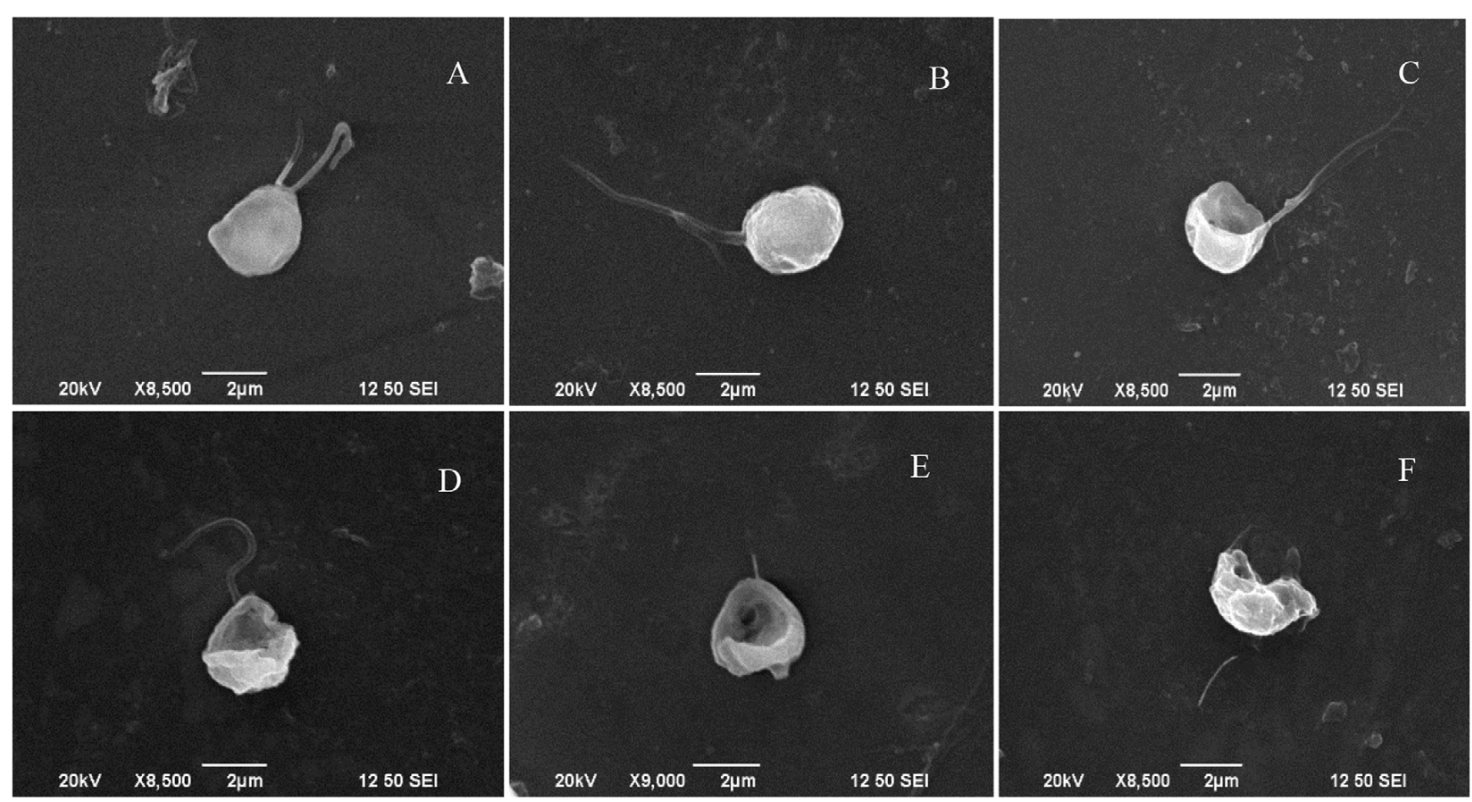

FIGURE 1 I SEM micrographs showing the morphology of algal cells treated with prodigiosin. (A,B) Control group; (C-F) cells treated for 12 , 24, 48, and 72 h, respectively. Scale bar $=2 \mu \mathrm{m}$.

Changes in nucleus structure were analyzed by confocal laser scanning microscope (CLSM, Zeiss LSM 780, Carl Zeiss, Jena, Germany). Algal cells were fixed with $1 \%$ paraformaldehyde, then washed and resuspended in PBS. Cells were then stained with $5 \mu \mathrm{g} / \mathrm{mL} \mathrm{4}$,6-diamidino-2-phenylindole (DAPI) for $15 \mathrm{~min}$ in the dark. After washing with PBS, algal cells were placed on slides for CLSM observation. DAPI fluorescence was read at $460 \mathrm{~nm}$ and represented with blue color on images. Chlorophyll fluorescence was monitored at $680 \mathrm{~nm}$ and represented with red color on images.

\section{Analysis of Cell Membrane Permeability}

For cell membrane permeability analysis, algal cells in treatment group were collected after $3,12,24,36$, and $48 \mathrm{~h}$, followed by PBS (50 mM, pH 7.4) washing. Cell membrane permeability was then analyzed by the fluorescent dye propidium iodide (PI; Invitrogen, United States) and detected by flow cytometry (FCM; Wang et al., 2010b). A total of $900 \mu \mathrm{L}$ algal cell solution (about $10^{6}-10^{7}$ cells $/ \mathrm{mL}$ ) stained with $100 \mu \mathrm{L}$ of PI at final concentration of $10 \mu \mathrm{g} / \mathrm{mL}$. The mixture were then stored for $15 \mathrm{~min}$ at room temperature in the dark, then analyzed by FCM according to our method reported previously (Zhang et al., 2015). About 10,000 cells were analyzed in each sample.

\section{Measurement of Fluorescence of Pigments and Chlorophyll}

To analyze the contents of chlorophyll $a(\mathrm{Chl} a)$ and carotenoid after prodigiosin treatment, $5 \mathrm{~mL}$ algal cultures were prepared as described above. Algal pigments were then extracted with $90 \%$ ethanol at $4^{\circ} \mathrm{C}$ in the dark, overnight (Ritchie, 2006). After cells removed by centrifugation, the supernatants absorbance was tested at 665,645 , and $470 \mathrm{~nm}$. Chl $a$ and carotenoid content was calculated using the following formulas:

$$
\begin{aligned}
& \text { Chlorophyll a }(\mathrm{mg} / \mathrm{L})=12.7 * A_{665}-2.69 * A_{645} \\
& \text { Carotinoid }(\mathrm{mg} / \mathrm{L})= \\
& \left(1,000 * A_{470}-2.05 * C_{\text {Chlorophyll a }}\right) / 245
\end{aligned}
$$

Chl $a$ fluorescence was also detected by FCM as described above, but fluorescence intensity was collected using a 630-nm filter (FL4).

Pulse amplitude modulation (PAM) fluorescence indicating photosynthesis efficiency was measured by PAM-CONTROL Fluorometer (Walz, Effeltrich, Germany). The algal fluorescence was detected using an actinic light of 3,000 $\mu \mathrm{mol}$ photons $\mathrm{m}^{-2} \mathrm{~s}^{-1}$ after dark adaptation for $15 \mathrm{~min}$. The maximum photochemical quantum yield of photosystem $\left(F_{\mathrm{v}} / F_{\mathrm{m}}\right)$ which is the indicator of photosynthesis was obtained (Schreiber et al., 2007).

\section{The Photosynthesis-Related Genes Expression Assays}

To analyze the effect of prodigiosin on the genes expression, total RNA was extracted from $50 \mathrm{~mL}$ algal cells treated for 12, 24, and $36 \mathrm{~h}$ using the RNAiso kit (TaKaRa Company). Two photosynthesis-related genes were analyzed using specific primers: 5'-AGTTGCTGGTTCTCTACTTTACG-3' (forward) and 5'-TTCCCACTCA CGACCGATG-3' (reverse) for the psbA gene; $5^{\prime}$-AAGTCTTACTGGGAAATGTG G G-3' (forward) and $5^{\prime}$-AGCAGGACGCTGAACGATG-3' (reverse) for the $r b c S$ 

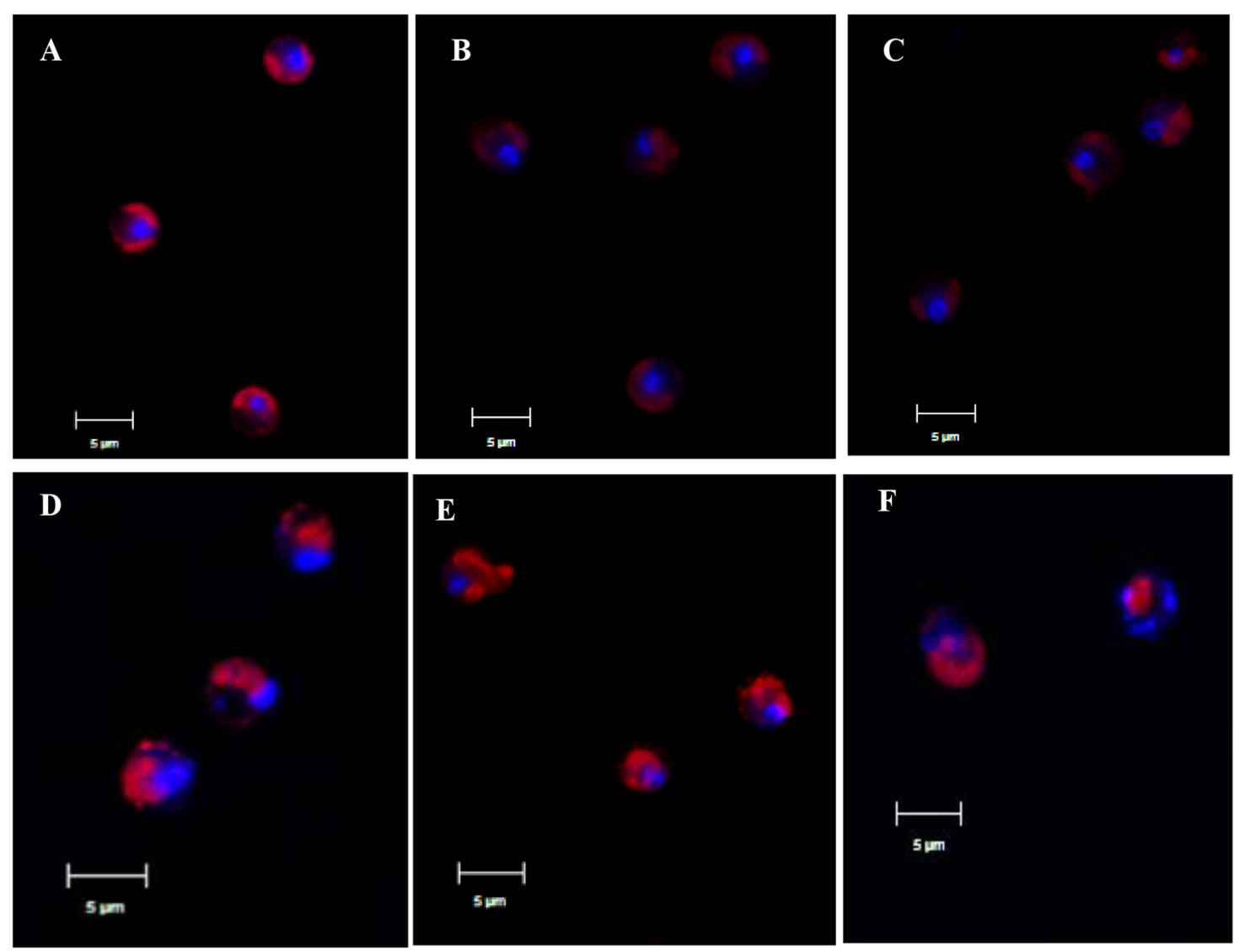

FIGURE 2 | Representative CLSM micrographs of control algal cells (A) or cells treated with prodigiosin (5 $\mathrm{\mu g} / \mathrm{mL})$ for 12, 24, 36, 48, and $72 \mathrm{~h}$ (B-F). Chlorophyll autofluorescence is shown in red, and the nucleus stained with 4',6-diamidino-2-phenylindole (DAPI) is shown in blue. Scale bar $=5 \mu \mathrm{m}$.

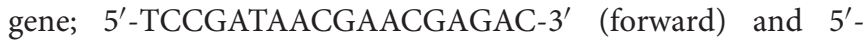
TGACGCAAAC TTCCACTT-3' (reverse) for the 18S rRNA gene. Quantitative real-time polymerase chain reaction (PCR) was performed under the following conditions: denaturation at $95^{\circ} \mathrm{C}$ for $3 \mathrm{~min}$, then 40 cycles at $95^{\circ} \mathrm{C}$ for $10 \mathrm{~s}$, and $55^{\circ} \mathrm{C}$ for 30 s. Meanwhile, $18 \mathrm{~S}$ rRNA gene was employed as reference gene to normalize gene expression changes. Gene expression was quantified using the $2^{-\Delta \Delta \mathrm{Ct}}$ method (Livak and Schmittgen, 2001).

\section{Statistical Analysis}

All triplicate data analyzed with mean \pm standard error and variance compared using one-way analysis of variance (ANOVA), followed by the least significant difference test (Origin 9.0 for Windows).

\section{RESULTS}

\section{Cell Morphology under Prodigiosin Treatment}

It had been proved that $5 \mu \mathrm{g} / \mathrm{mL}$ prodigiosin produced $84 \%$ algicidal activity in $72 \mathrm{~h}$ (Zhang et al., 2016). In the present research, the algicidal process of prodigiosin on $P$. globosa was further analyzed by SEM (Figure 1). Normal algal cells exhibited one or two flagella (Figures 1A,B) indicating ability for high motility. When algae were treated with prodigiosin for 12 and $24 \mathrm{~h}$, many cells had ruptured and had partially lost cell structure (Figures 1C,D). As exposure time increased, algal cells lysed and the cell structure was destroyed with cellular components released from cells, finally resulting in cell disintegration (Figures 1E,F). Flagella lost from the cells as exposure time increased, indicating that prodigiosin could affect cell motility.

\section{Nucleus Damage from Prodigiosin Treatment}

CLSM revealed more details on the morphology of the nucleus after prodigiosin treatment (Figure 2). In control cells, chromatin is concentrated in the center of cells, as indicated by strong and even red autofluorescence and also DAPI blue emission (Figure 2A). However, chromatin displacement was observed after $24 \mathrm{~h}$ of prodigiosin treatment (Figure 2C), as algal cells became irregular. After $36 \mathrm{~h}$ of treatment, diffusion of the degraded DNA was observed (Figure 2D). As prodigiosin treatment time increased, the presence of 

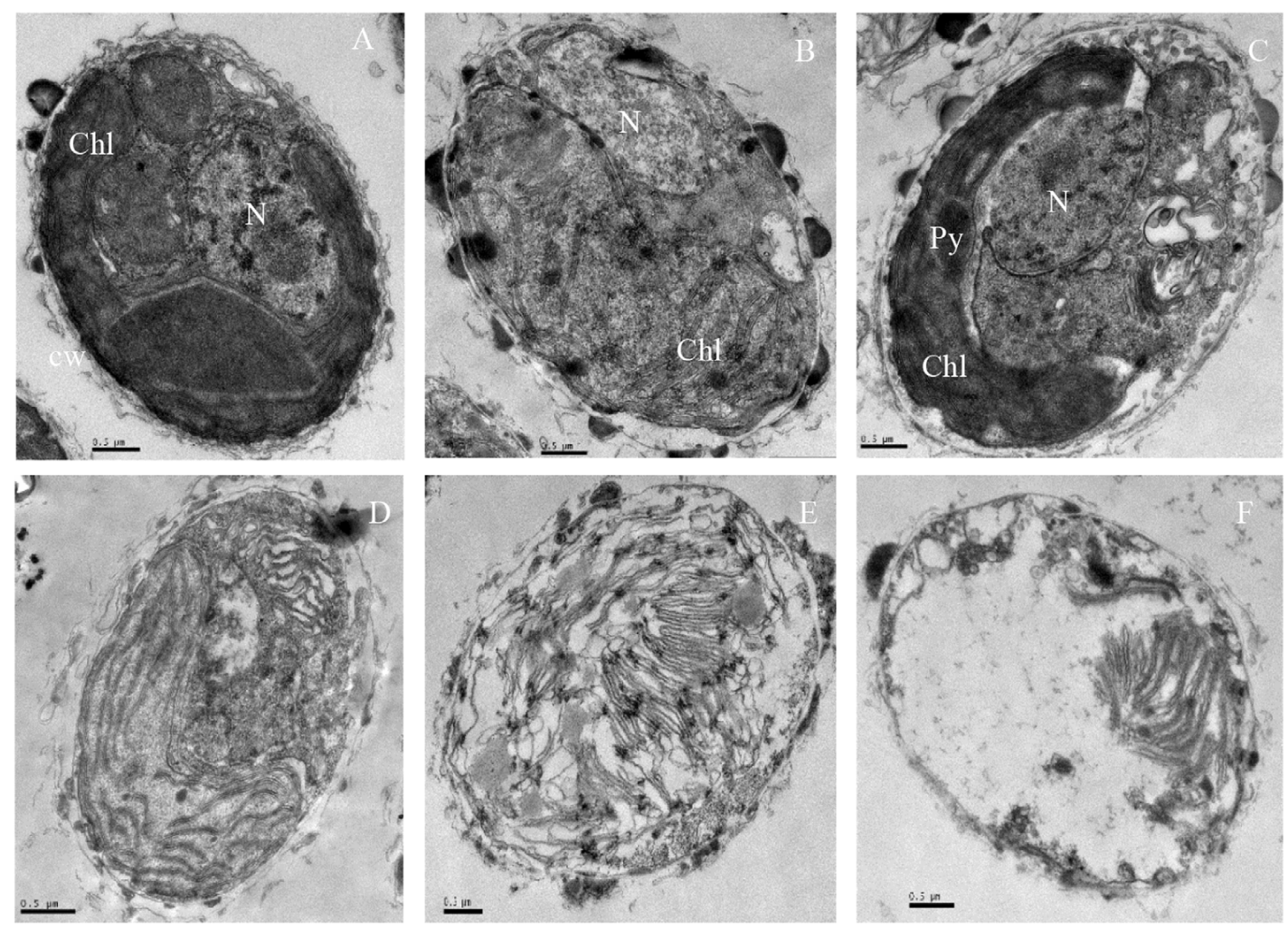

FIGURE 3 | TEM micrographs showing the ultrastructure of algal cells treated with $5 \mu \mathrm{g} / \mathrm{mL}$ prodigiosin. (A) Control cells; (B-F) $12,24,36$, 48, and $72 \mathrm{~h}$ of treatment; N, nucleus; Chl, chloroplast; Py, pyrenoid; Scale bars $=0.5 \mu \mathrm{m}$

DAPI fluorescence around the cells evidenced further DNA fragmentation and chromatin displacement (Figures 2E,F). Autofluorescence of chlorophyll also evidenced serious cell deformation (Figures 2C-F). Release of cellular inclusions and cell cleavage were similar to those observed by SEM analysis.

\section{Subcellular Structure Changes after Prodigiosin Treatment}

The ultrastructure of algal cells was compared between control cells and cells treated with $5 \mu \mathrm{g} / \mathrm{mL}$ prodigiosin (Figure 3). In control cells (Figure 3A), we could observe a normal nucleus, chloroplasts, mitochondria, and other organelles. After prodigiosin treatment, algal cells exhibited various structural differentiation, including morphological alterations and impairment. After 12 (Figure 3B) and $24 \mathrm{~h}$ (Figure 3C) of prodigiosin treatment, algal cells showed cytoplasmic hypervacuolization and were not as compact as control cells; however, the nuclear morphology was still normal at this time point. After 36 (Figure 3D) and $48 \mathrm{~h}$ (Figure 3E) of treatment, the vacuolization of the cytoplasmic intensified and many organelles broke up, including the chloroplasts and the nucleus. Algal cells treated with prodigiosin for $72 \mathrm{~h}$ (Figure 3F) showed extreme plasmolysis and vacuolization. Moreover, cellular inclusions released from cells, leaving a relatively intact cell wall, indicating that cells had completely lost vital activities.

\section{Integrity of Cell Membrane}

PI enters into living cells through permeabilized membranes, then intercalates into DNA or RNA emitting red fluorescence (Davey and Hexley, 2011). When algal cells were stained with PI after prodigiosin treatment, the fluorescence in the nucleus did not change significantly (Figure 4). The proportion of normal cells were $99.6 \%$ in the cytogram of untreated algal cells (Figure 4A, P1), while cells in P2 were permeabilized cells. Our data showed that most algal cells lysed in $48 \mathrm{~h}$, but the membrane of remaining living cells was not affected by prodigiosin.

\section{Responses of Enzyme Activities to Prodigiosin Treatment}

Excessive ROS can cause damage to molecules and cell structure. ROS increased rapidly after $2 \mathrm{~h}$ in cells treated with $5 \mu \mathrm{g} / \mathrm{mL}$ prodigiosin (Figure 5A) that were about fivefold higher than those of untreated cells. After that, ROS levels returned to a relative normal levels. To determine the cellular damage caused by ROS, we analyzed the MDA content which is a natural biomarker of the lipid peroxidation process (Sathasivam et al., 2016). MDA content in algal cells increased slightly after $36 \mathrm{~h}$ of exposure to prodigiosin, relative to the control (Figure 5B). After that, it increased remarkably $(P<0.01)$ after $48 \mathrm{~h}$ of treatment (3.32-fold; $P<0.01)$, reaching maximum value at $72 \mathrm{~h}$ of treatment (4.45-fold; $P<0.01)$. 

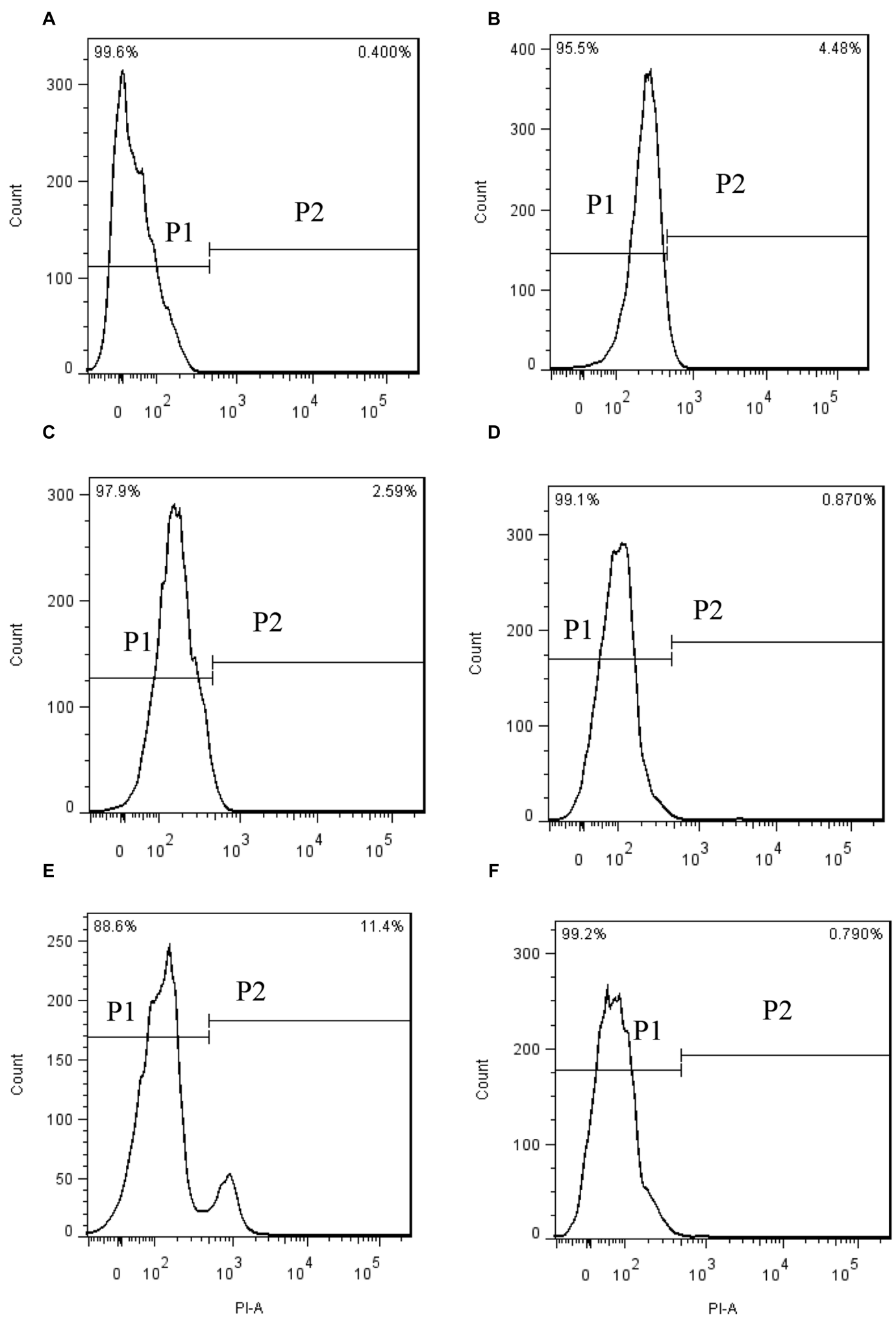

FIGURE 4 | PI fluorescence density histogram indicating the integrity of algal cell membranes after different times of treatment with prodigiosin. (A) Control; (B-F) cells treated for $3,12,24,36$, and 48 h, respectively. Quadrant P1: cells without PI fluorescence. Quadrant P2: abnormal cells with PI fluorescence. 

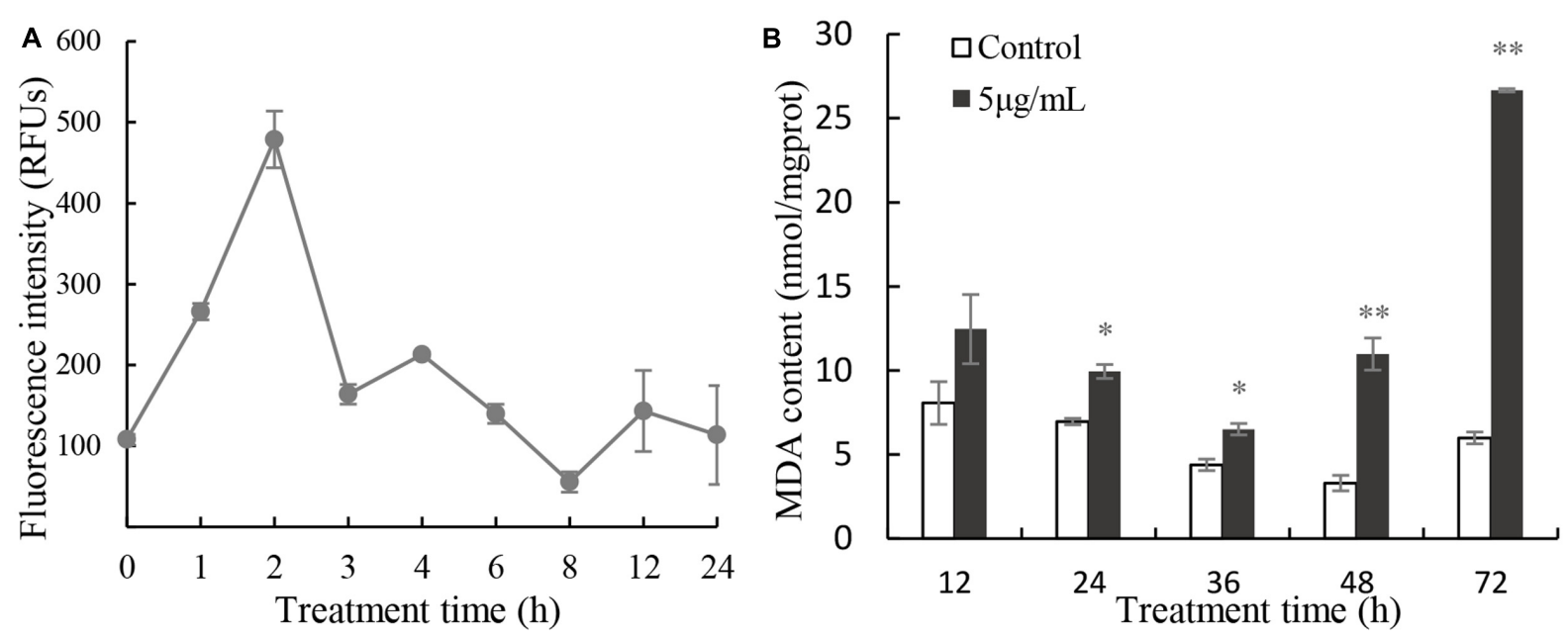

FIGURE 5 | Intracellular ROS (A) production and MDA content (B) in cells treated with $5 \mu \mathrm{g} / \mathrm{mL}$ prodigiosin. Data are mean of three independent experiments \pm SE, with the statistic of ${ }^{* *} P<0.01$ and $* P<0.05$.
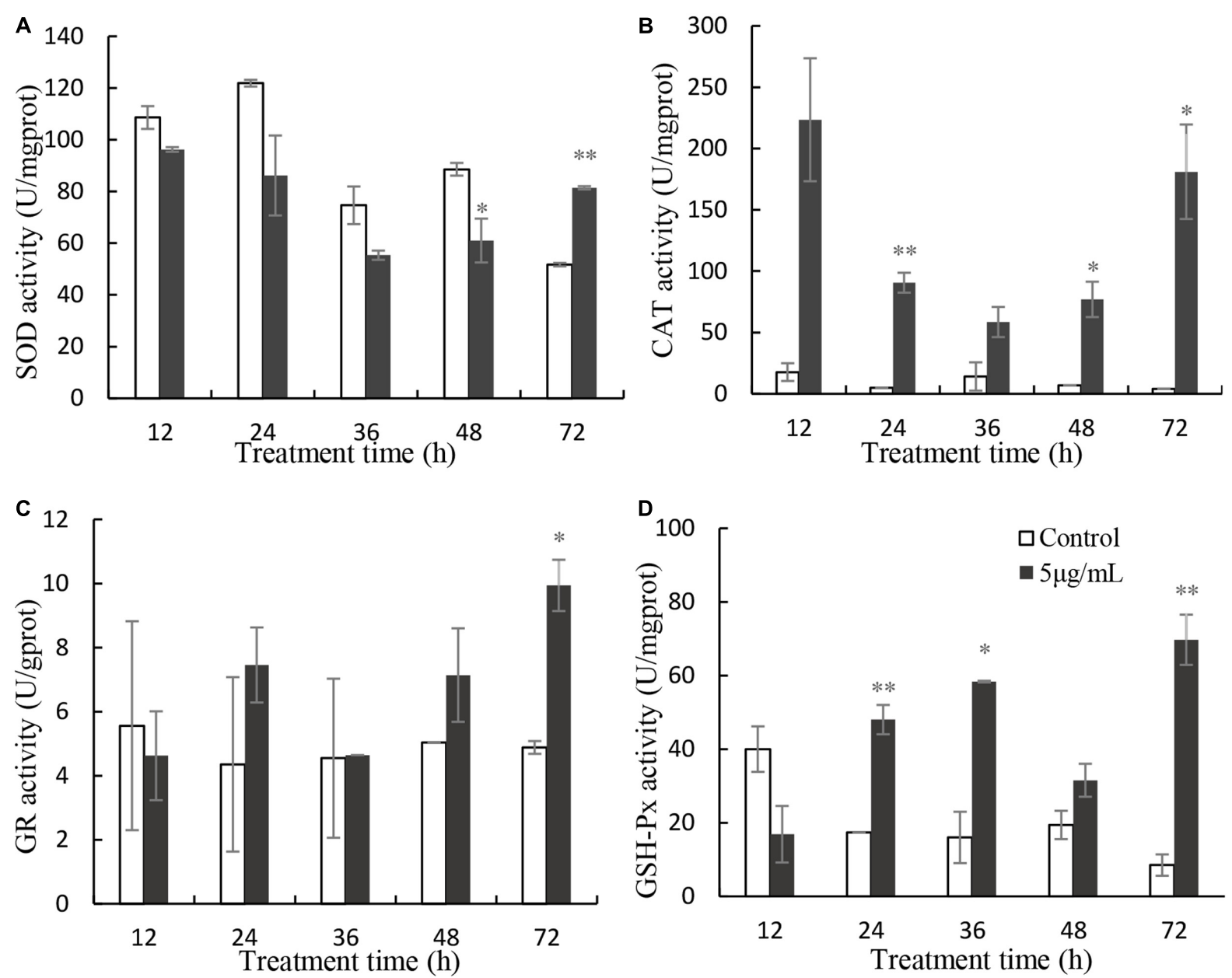

FIGURE 6 | Effects of prodigiosin treatment (5 $\mu \mathrm{g} / \mathrm{mL})$ on the activity of SOD (A), CAT (B), GR (C), and GPx (D). Data are mean of three independent experiments $\pm \mathrm{SE}$, with the statistic of $* * P<0.01$ and ${ }^{*} P<0.05$. 


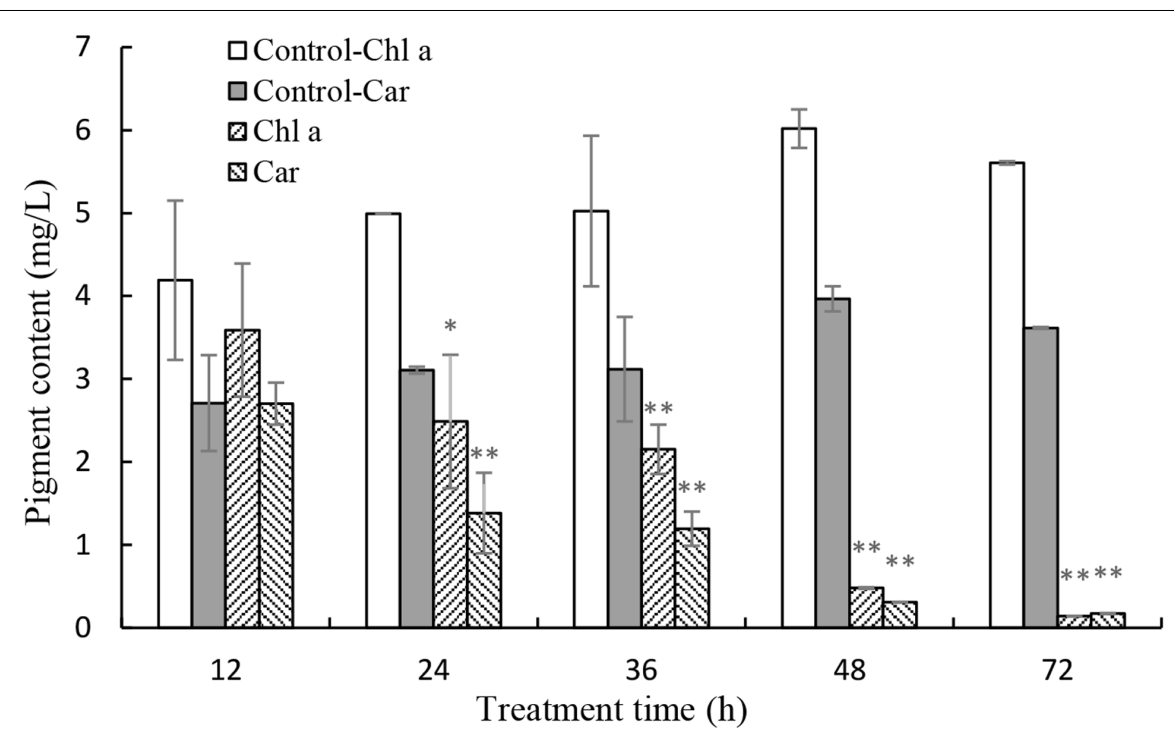

FIGURE 7 | Effects of prodigiosin treatment $(5 \mu \mathrm{g} / \mathrm{mL})$ on the contents of Chl a and carotenoid. Data are mean of three independent experiments \pm SE, with the statistic of ${ }^{* *} P<0.01$ and ${ }^{*} P<0.05$.

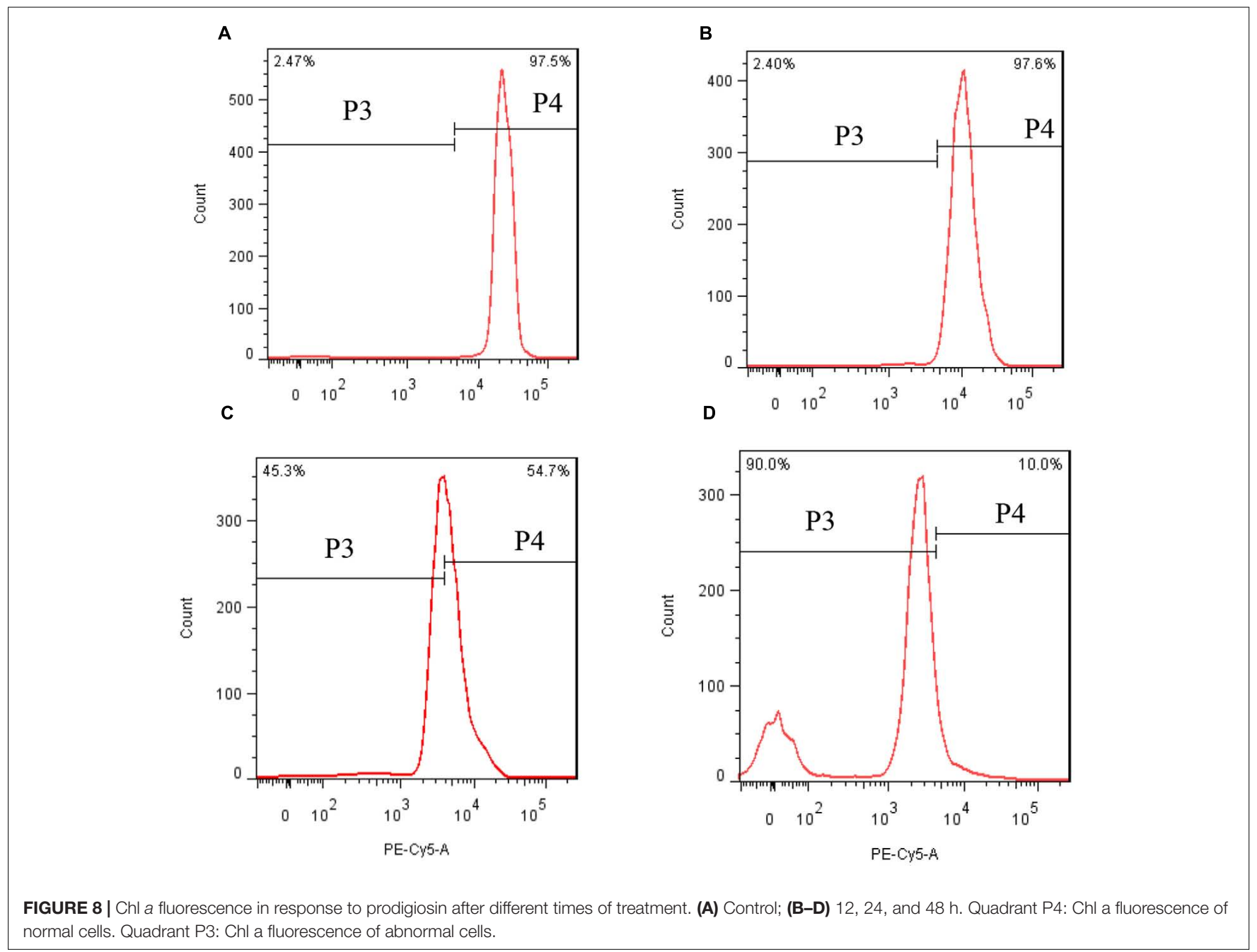




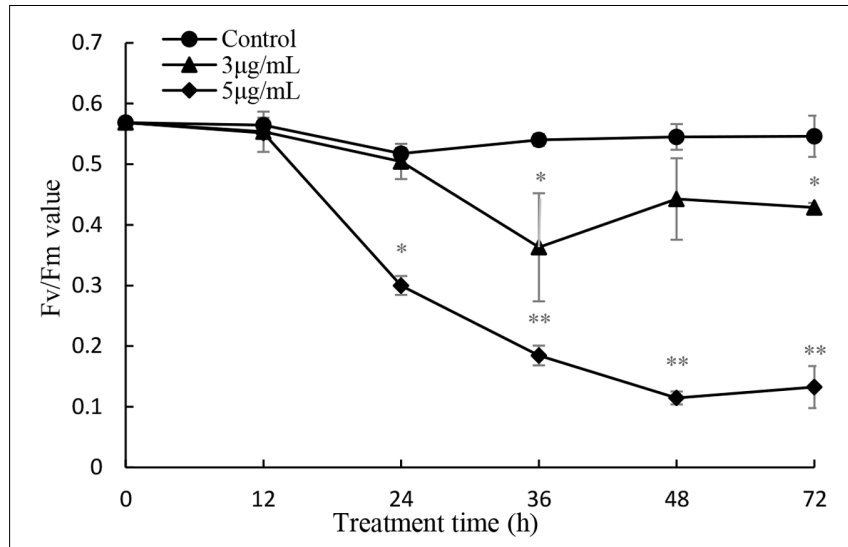

FIGURE 9 | Influence of prodigiosin on photosynthetic efficiency $\left(F_{\mathrm{v}} / F_{\mathrm{m}}\right)$ of $P$. globosa. Data are mean of three independent experiments $\pm \mathrm{SE}$, with the statistic of ${ }^{* *} P<0.01$ and $* P<0.05$.

SOD activity decreased slightly, relative to the control after 12 , 24, 36, and $48 \mathrm{~h}$ exposure, but it increased significantly after $72 \mathrm{~h}$ treatment (Figure 6A). The values of SOD were 0.89, 0.71, 0.74, $0.69(P<0.05)$ and 1.57 times $(p<0.01)$ those of the control at $12,24,36,48$, and $72 \mathrm{~h}$ treatment. CAT activity increased significantly, relative to the untreated cells (Figure 6B), after 12 h (12.64-fold), 24 h (18.52-fold; $P<0.01)$, 36 h (4.15-fold), 48 h (11.38-fold; $P<0.05)$, and 72 h (45.15-fold; $P<0.05)$ of exposure to $5 \mu \mathrm{g} / \mathrm{mL}$ prodigiosin. GR activity did not change markedly in the first $48 \mathrm{~h}$ of prodigiosin treatment, but increased after $72 \mathrm{~h}$ (2.04-fold; $P<0.05)$ treatment (Figure 6C). The effect of prodigiosin on GPx activity was similar to its effect on CAT activity (Figure 6D). After $24 \mathrm{~h}$, and $36 \mathrm{~h}$ of treatment, GPx activity obviously increased $(P<0.01)$. Although GPx activity decreased at $48 \mathrm{~h}$ of treatment, it increased markedly $(P<0.01)$ after $72 \mathrm{~h}$ reaching its maximum.

\section{Algal Photosystem Responses}

In order to investigate the stress of prodigiosin on the photosynthesis process, Chl $a$ and carotenoid contents were determined. Chl $a$ contents decreased, relative to untreated cells, after $12 \mathrm{~h}$ of exposure to prodigiosin $(P<0.05$; Figure 7$)$. As exposure time increased, $\mathrm{Chl} a$ contents decreased. Chl $a$ contents in control were 12.6-fold at $48 \mathrm{~h}(P<0.01)$, and 39.3 -fold at $72 \mathrm{~h}$ $(P<0.01)$, relative to prodigiosin-treated cells. The carotenoids contents in algal cells changed in a way similar to Chl $a$. After 36,48 , and $72 \mathrm{~h}$, carotenoids contents in control cells were about 2.60-, 12.75-, and 20.88-fold, respectively, relative to cells treated with prodigiosin. FCM analysis of Chl a fluorescence showed a remarkable change after prodigiosin treatment (Figure 8). About $97.5 \%$ of the untreated control cells had relative normal Chl $a$ fluorescence (quadrant P4). Chl $a$ fluorescence was not affected by prodigiosin in $97.6 \%$ of the cells after 12 -h treatment (Figure 8B), but fluorescence decreased after 24 (Figure 8C) and $48 \mathrm{~h}$ (Figure 8D) of treatment. About $45.3 \%$ and $90.0 \%$ of algal cells lost Chl $a$ fluorescence at 24 and $48 \mathrm{~h}$ of treatment, respectively.

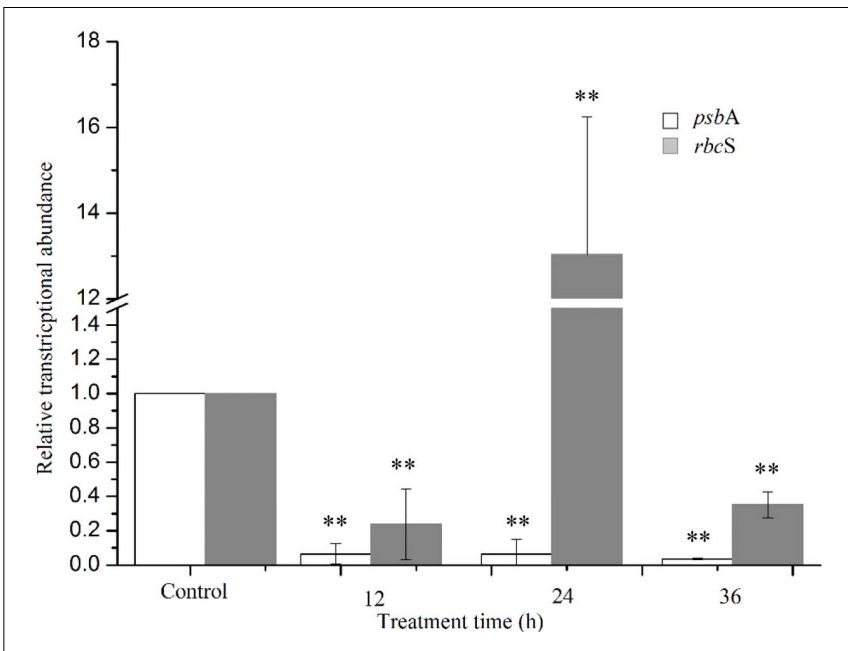

FIGURE 10 | Relative normalized expression of psbA and $r b c S$ genes in algal cells treated with $5 \mu \mathrm{g} / \mathrm{mL}$ prodigiosin. Data are mean of three independent experiments $\pm \mathrm{SE}$, with the statistic of $* * P<0.01$ and $* P<0.05$.

The maximum photochemical quantum yield $\left(F_{\mathrm{v}} / F_{\mathrm{m}}\right)$ was employed to detect the photosynthetic status of the cells after prodigiosin treatment at 3 and $5 \mu \mathrm{g} / \mathrm{mL}$ (Figure 9). After $24 \mathrm{~h}$ of treatment, the $F_{\mathrm{v}} / F_{\mathrm{m}}$ value was remarkably $(P<0.05)$ lower than that of control cells when treated with $5 \mu \mathrm{g} / \mathrm{mL}$ prodigiosin. After $36 \mathrm{~h}$ of treatment, the $F_{\mathrm{v}} / F_{\mathrm{m}}$ value decreased significantly. $F_{\mathrm{v}} / F_{\mathrm{m}}$ values were lower in $5 \mu \mathrm{g} / \mathrm{mL}$ treatment group indicating that the inhibition in photosystem II (PSII) by prodigiosin was dose-depended.

Two target genes were investigated to explore the extent of damage to the photosystem (Figure 10). The $p s b A$ gene encodes the reaction center D1 protein of photosystem, which participates in the PSII photodamage repair process. Gene expression analysis was performed at $36 \mathrm{~h}$ of treatment, because RNA quality was not suitable for qPCR analysis after longer treatment times. The results showed that the $p s b A$ gene expression was significantly inhibited $(P<0.01)$ at all times of exposure, providing evidence for the inhibition of the photodamage repair process. The expression of $r b c S$ gene reduced obviously $(P<0.01)$ after $12 \mathrm{~h}$ exposure, and then increased markedly $(P<0.01)$ after $24 \mathrm{~h}$, indicating that algal cells could provide more energy to resist prodigiosin stress. As exposure time increased, prodigiosin continued to destroy cells and $r b c S$ gene expression decreased again. These results indicate that the photodamage repair process was inhibited at $12 \mathrm{~h}$, and that carbon fixation process was inhibited at $36 \mathrm{~h}$. These results indicated that prodigiosin treatment induced photosynthesis inhibition at short time points, which may be finally related to algal cell death.

\section{DISCUSSION}

In our previous study, we found that strain KA22 could secrete prodigiosin exhibiting effective algicidal activity on $P$. globosa (Zhang et al., 2016). Prodigiosin possesses a huge advantage on the control of HAB because it could degrade naturally in 


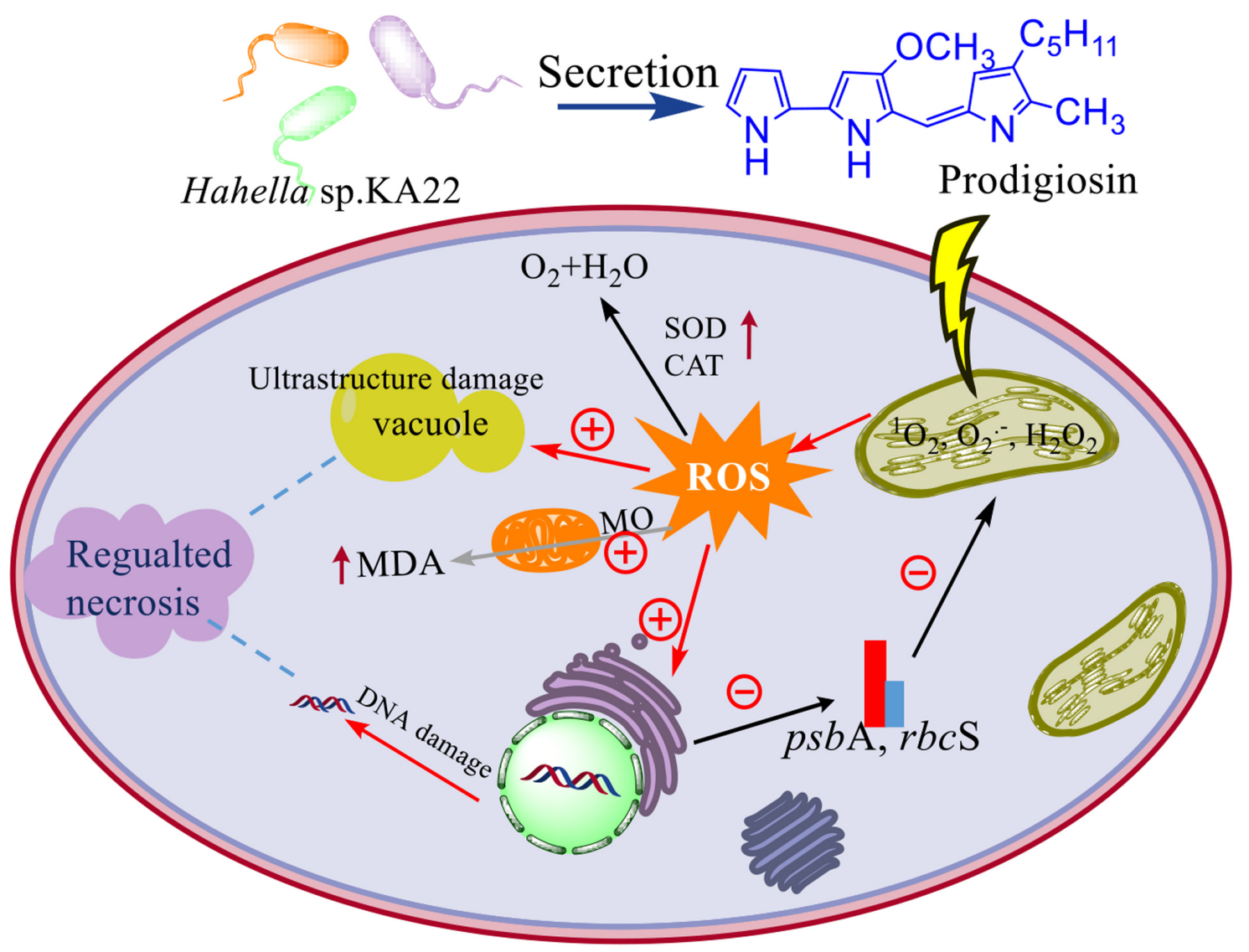

FIGURE 11 | The model of algicidal mechanism of prodigiosin on P. globosa. $\oplus$ represents the promoted process; •represents the inhibited process; the increased enzyme activity and the MDA contents were represented by the up arrow; MO means membrane oxidative damage.

environment avoiding persistence in marine waters (Zhang et al., 2016). In this work, we explored the mechanism of prodigiosin killing $P$. globosa, which will provide detail biological safety and ecological information for the usage of prodigiosin in environment in the future.

External stress can stimulate algal cells to generate excessive ROS, which could give rise to severe cellular damage or cell death. Our results showed that prodigiosin caused a ROS burst in $P$. globosa after a short time of treatment (Figure 5), which may ultimately lead to cell death. ROS could cause oxidative damage to algal cells, as evidenced by MDA contents (Figure 5), despite the activation of the antioxidant system (Figure 6). Increased ROS levels also induced DNA and nucleus damage, as evidenced by degraded chromatin, and a dispersed nucleus (Figures 2, 3), which are features of necrotic cell death (Zong et al., 2004; Van Doorn et al., 2011). Moreover, ROS is well known to produce algal cells necrosis (Berghe et al., 2014).

It is known that exposure of unicellular alga to environmental stress induces disparate morphotypes of cell death (Jimenez et al., 2009). Few studies have focused on the ultrastructure of P. globosa, especially under external stress. We observed clear differences in ultrastructure between cells treated with prodigiosin and untreated cells, which indicated that prodigiosin produced necrosis (Figure 3). Cytoplasmic vacuolization, organelle decomposition, nuclear rupture, were typical characteristics of cell necrosis that were observed by TEM in this study. Our findings suggest that prodigiosin promoted some cells to undergo necrosis via ROS. To our knowledge, this is the first report for the necrosis of $P$. globosa cells induced by an algicidal pigment.

Chl $a$ fluorescence analyzed by FCM was employed to detect response of photosynthesis to external stress. In fact, this method is frequently applied in toxicological and eco-physiological studies to detect the consequences of environmental alteration and pollutants on algae and higher plant. Prodigiosin showed obviously inhibitory effect on Chl $a$ fluorescence after long exposure time, which may be the result of the inhibition during electron flow process in the PSII system (Figure 8). Another photosynthesis parameter, $F_{\mathrm{v}} / F_{\mathrm{m}}$, may support our finding further (Figure 9). It is evident that environmental factors impacting the PSII, directly or indirectly, will also impact the $F_{\mathrm{v}} / F_{\mathrm{m}}$ values (Kumar et al., 2014). In the presence of light, abiotic and biotic stress often decrease $F_{\mathrm{V}} / F_{\mathrm{m}}$ in plants. Baker (Baker, 2008) suggested that $F_{\mathrm{V}} / F_{\mathrm{m}}$ measurement is as a simple and rapid way of monitoring stress in plants. Our results showed that 
$F_{\mathrm{v}} / F_{\mathrm{m}}$ decreased as prodigiosin treatment time increased, which provided evidence for PSII system dysfunction. This dysfunction transferred excitation energy to ROS as singlet oxygen. Chl $a$ and carotenoid content decreased (Figure 7), reducing the inhibition capacity of ROS generation. Carotenoids are important antioxygenic micromolecule in photosynthesis organisms, which could quench the excited triplet state of chlorophyll, thus preventing excessive ROS generation (Larkum, 2016).

D1 protein, including in the reaction center of PSII, holds important redox components involved in the photosynthetic charge separation and subsequent reduction of plastoquinone (Mulo et al., 2012). Wu et al. (2014) had reported that the highly oxidative chemistry of water splitting could induce severely damage to the PSII system. The D1 protein is the main objective of this damage, but it could sacrify itself to block PSII inactivation. In other words, the D1 protein is constantly degraded and re-synthesized in the cycle called PSII repair cycle under normal photosynthetic conditions. Our results showed that algal cells treated with prodigiosin reduced $p s b \mathrm{~A}$ expression significantly, which suggests that the disturbance of D1 protein synthesis process inducing serious oxidative damage to PSII (Figure 10). RuBisCO, encoded by $r b c S$ and $r b c \mathrm{~L}$ genes, has important function in carbon fixation in plants and algae (Atkinson et al., 2015). The $r b c S$ gene was first downregulated, and then upregulated at $24 \mathrm{~h}$, indicating that cells try to fix more $\mathrm{CO}_{2}$ to resist external stress. The $r b c \mathrm{~S}$ gene was also inhibited by prodigiosin as treatment time increased. These results indicate that the photochemical reaction in PSII and the carbon fixation system were completely inhibited by prodigiosin.

Although prodigiosin was reported as an efficient algicidal compound years ago, this is the first repot exploring its algicidal mechanisms on P. globosa. Because of its high algicidal activity and natural degradation characteristics, prodigiosin has great

\section{REFERENCES}

Affenzeller, M. J., Darehshouri, A., Andosch, A., Lutz, C., and Lutz-Meindl, U. (2009). Salt stress induced cell death in the unicellular green alga Micrasterias denticulata. J. Exp. Bot. 60, 939-954. doi: 10.1093/jxb/ern348

Anderson, D. M., Cembella, A. D., and Hallegraeff, G. M. (2012). Progress in understanding harmful algal blooms: paradigm shifts and new technologies for research, monitoring, and management. Annu. Rev. Mar. Sci. 4, 143-176. doi: 10.1146/annurev-marine-120308-081121

Atkinson, N., Feike, D., Mackinder, L., Meyer, M. T., Griffiths, H., Jonikas, M. C., et al. (2015). Introducing an algal carbon-concentrating mechanism into higher plants: location and incorporation of key components. Plant Biotechnol. J. 14, 1302-1315. doi: 10.1111/pbi.12497

Baker, N. R. (2008). Chlorophyll fluorescence: a probe of photosynthesis in vivo. Annu. Rev. Plant Biol. 59, 89-113. doi: 10.1146/annurev.arplant.59.032607. 092759

Berghe, T. V., Linkermann, A., Jouan-Lanhouet, S., Walczak, H., and Vandenabeele, P. (2014). Regulated necrosis: the expanding network of non-apoptotic cell death pathways. Nat. Rev. Mol. Cell Biol. 15, 135-147. doi: $10.1038 / \mathrm{nrm} 3737$

Choudhary, M., Jetley, U. K., Khan, M. A., Zutshi, S., and Fatma, T. (2007). Effect of heavy metal stress on proline, malondialdehyde, and superoxide dismutase activity in the cyanobacterium Spirulina platensis-S5. Ecotoxicol. Environ. Safe 66, 204-209. doi: 10.1016/j.ecoenv.2006.02.002 potential as an algicide for the regulation of red tide occurrence. Therefore, based on the above analysis, we proposed the model of algicidal mechanism of prodigiosin on P. globosa (Figure 11). The model suggests that prodigiosin strongly inhibits photosynthesis, promoting excessive ROS generation, which may induce severe oxidative damage to cells and organelles. Our results indicate that algal cells undergo necrosis promoted by ROS when they are treated with prodigiosin. Further studies, including the analysis of algicidal effects on harmful algae present in a microcosm, are essential, prior to the application in the control of red tides.

\section{AUTHOR CONTRIBUTIONS}

$\mathrm{HZ}$ contributed for conception and design, drafting of the article, technical and logistic support, analysis and interpretation of the data. HW contributed for collection and assembly data and analysis the data. WZ, ZY, YP, and SZ contributed for statistical expertise and collection and assembly data. $\mathrm{ZH}$ and ZT contributed for critical revision of the article for important intellectual content. TZ contributed for obtaining of funding and final approval of the article. All authors had reviewed the manuscript.

\section{FUNDING}

This study was funded by the National Natural Science Foundation of China (41376119, 41676116, 31500095, 41601517), Zhejiang Provincial Natural Science Foundation of China (LQ17D060001), the Natural Science Foundation of Ningbo (2016A610094), Natural Science Foundation (XYL16011) of Ningbo University, and K.C.Wong Magna Fund in Ningbo University.

Davey, H., and Hexley, P. (2011). Red but not dead? Membranes of stressed Saccharomyces cerevisiae are permeable to propidium iodide. Environ. Microbiol. 13, 163-171. doi: 10.1111/j.1462-2920.2010.02317.x

Guo, P., Liu, Y., and Liu, C. (2015). Effects of chitosan, gallic acid, and algicide on the physiological and biochemical properties of Microcystis flos-aquae. Environ. Sci. Pollut. R 22, 13514-13521. doi: 10.1007/s11356-015-4500-0

Heisler, J., Glibert, P. M., Burkholder, J. M., Anderson, D. M., Cochlan, W., Dennison, W. C., et al. (2008). Eutrophication and harmful algal blooms: a scientific consensus. Harmful Algae 8, 3-13. doi: 10.1016/j.hal.2008.08.006

Jeong, H., Yim, J. H., Lee, C., Choi, S. H., Park, Y. K., Yoon, S. H., et al. (2005). Genomic blueprint of Hahella chejuensis, a marine microbe producing an algicidal agent. Nucleic Acids Res. 33, 7066-7073. doi: 10.1093/nar/gki1016

Jimenez, C., Capasso, J. M., Edelstein, C. L., Rivard, C. J., Lucia, S., Breusegem, S., et al. (2009). Different ways to die: cell death modes of the unicellular chlorophyte Dunaliella viridis exposed to various environmental stresses are mediated by the caspase-like activity DEVDase. J. Exp. Bot. 60, 815-828. doi: 10.1093/jxb/ern330

Kim, D., Kim, J. F., Yim, J. H., Kwon, S. K., Lee, C. H., and Lee, H. K. (2008). Red to red-the marine bacterium Hahella chejuensis and its product prodigiosin for mitigation of harmful algal blooms. J. Microbiol. Biotechnol. 18, 1621-1629.

Kirilovsky, D. (2015). Photosynthesis: dissipating energy by carotenoids. Nat. Chem. Biol. 11, 242-243. doi: 10.1038/nchembio.1771

Kumar, K. S., Dahms, H. U., Lee, J. S., Kim, H. C., Lee, W. C., and Shin, K. H. (2014). Algal photosynthetic responses to toxic metals and herbicides assessed 
by chlorophyll a fluorescence. Ecotoxicol. Environ. Safe 104, 51-71. doi: 10.1016/ j.ecoenv.2014.01.042

Larkum, A. W. (2016). "Photosynthesis and light harvesting in algae," in The Physiology of Microalgae, eds M. A. Borowitzka, J. Beardall, and J. A. Raven (Berlin: Springer), 67-87.

Li, L., and Pan, G. (2013). A universal method for flocculating harmful algal blooms in marine and fresh waters using modified sand. Environ. Sci. Technol. 47, 4555-4562. doi: 10.1021/es305234d

Livak, K. J., and Schmittgen, T. D. (2001). Analysis of relative gene expression data using real-time quantitative PCR and the 2- $\Delta \Delta \mathrm{ct}$ Method. Methods 25, 402-408. doi: 10.1006/meth.2001.1262

Mulo, P., Sakurai, I., and Aro, E. M. (2012). Strategies for psbA gene expression in cyanobacteria, green algae and higher plants: from transcription to PSII repair. BBA-Bioenergetics 1817, 247-257. doi: 10.1016/j.bbabio.2011. 04.011

Peperzak, L., and Gäbler-Schwarz, S. (2012). Current knowledge of the life cycles of Phaeocystis globosa and Phaeocystis antarctica (prymnesiophyceae). J. Phycol. 48, 514-517. doi: 10.1111/j.1529-8817.2012.01136.x

Pérez-Tomás, R., Montaner, B., Llagostera, E., and Soto-Cerrato, V. (2003). The prodigiosins, proapoptotic drugs with anticancer properties. Biochem. Pharmacol. 66, 1447-1452. doi: 10.1016/S0006-2952(03)00496-9

Rastogi, R. P., Singh, S. P., Häder, D.-P., and Sinha, R. P. (2010). Detection of reactive oxygen species (ROS) by the oxidant-sensing probe $2^{\prime}, 7^{\prime}$ dichlorodihydrofluorescein diacetate in the cyanobacterium Anabaena variabilis PCC 7937. Biochem. Biophys. Res. Commun. 397, 603-607. doi: $10.1016 / j . b b r c .2010 .06 .006$

Ritchie, R. J. (2006). Consistent sets of spectrophotometric chlorophyll equations for acetone, methanol and ethanol solvents. Photosynth. Res. 89, 27-41. doi: 10.1007/s11120-006-9065-9

Roth, P. B., Twiner, M. J., Mikulski, C. M., Barnhorst, A. B., and Doucette, G. J. (2008). Comparative analysis of two algicidal bacteria active against the red tide dinoflagellate Karenia brevis. Harmful Algae 7, 682-691. doi: 10.1016/j.hal.2008. 02.002

Rousseau, V., Chrétiennot-Dinet, M.-J., Jacobsen, A., Verity, P., and Whipple, S. (2007). The life cycle of Phaeocystis: state of knowledge and presumptive role in ecology. Biogeochemistry 83, 29-47. doi: 10.1007/s10533-007-9085-3

Sanchez, D., Houde, M., Douville, M., De Silva, A. O., Spencer, C., and Verreault, J. (2015). Transcriptional and cellular responses of the green alga Chlamydomonas reinhardtii to perfluoroalkyl phosphonic acids. Aquat. Toxicol. 160, 31-38. doi: 10.1016/j.aquatox.2014.12.002

Sang, B. H., Kim, H. M., Kim, Y. H., Chang, W. L., Jang, E. S., Son, K. H., et al. (1998). T-cell specific immunosuppression by prodigiosin isolated from Serratia marcescens. Int. J. Immunopharmacol. 20, 1-13. doi: 10.1016/S0192-0561(97) 00062-3

Sathasivam, R., Ebenezer, V., Guo, R., and Ki, J. S. (2016). Physiological and biochemical responses of the freshwater green algae Closterium ehrenbergii to the common disinfectant chlorine. Ecotoxciol. Environ. Safe 133, 501-508. doi: 10.1016/j.ecoenv.2016.08.004

Schreiber, U., Quayle, P., Schmidt, S., Escher, B. I., and Mueller, J. F. (2007), Methodology and evaluation of a highly sensitive algae toxicity test based on multiwell chlorophyll fluorescence imaging. Biosens. Bioelectron. 22, 2554-2563. doi: 10.1016/j.bios.2006.10.018

Sheik, A. R., Brussaard, C. P., Lavik, G., Lam, P., Musat, N., Krupke, A., et al. (2014). Responses of the coastal bacterial community to viral infection of the algae Phaeocystis globosa. ISME J. 8, 212-225. doi: 10.1038/ismej.2013.135
Son, M., Baek, S. H., Shin, K., Choi, K. H., Kim, S. W., Ryu, J., et al. (2015). Effects of the algicide, thiazolidinedione derivative TD49, on microbial communities in a mesocosm experiment. Environ. Monit. Assess. 187, 163-172. doi: 10.1007/ s10661-015-4367-z

Van Doorn, W., Beers, E., Dangl, J. L., Franklin-Tong, V., Gallois, P., HaraNishimura, I., et al. (2011). Morphological classification of plant cell deaths. Cell Death Diff. 18, 1241-1246. doi: 10.1038/cdd.2011.36

Wang, B. X., Zhou, Y. Y., Bai, S. J., Su, J. Q., Tian, Y., Zheng, T. L., et al. (2010a). A novel marine bacterium algicidal to the toxic dinoflagellate Alexandrium tamarense. Lett. Appl. Microbiol. 51, 552-557. doi: 10.1111/j.1472-765X.2010. 02936.x

Wang, Y., Hammes, F., De Roy, K., Verstraete, W., and Boon, N. (2010b). Past, present and future applications of flow cytometry in aquatic microbiology. Trends Biotechnol. 28, 416-424. doi: 10.1016/j.tibtech.2010.04.006

Wu, Q., Su, N., Shen, W., and Cui, J. (2014). Analyzing photosynthetic activity and growth of Solanum lycopersicum seedlings exposed to different light qualities. Acta Physiol. Plant 36, 1411-1420. doi: 10.1007/s11738-014-1519-7

Zhang, H., An, X., Zhou, Y., Zhang, B., Zhang, S., Li, D., et al. (2013). Effect of oxidative stress induced by Brevibacterium sp. BS01 on a HAB causing species-Alexandrium tamarense. PLoS ONE 8:63018. doi: 10.1371/journal.pone. 0063018

Zhang, H., Peng, Y., Zhang, S., Cai, G., Li, Y., Yang, X., et al. (2016). Algicidal effects of prodigiosin on the harmful algae Phaeocystis globosa. Front. Microbiol. 7:602 doi: $10.3389 /$ fmicb.2016.00602

Zhang, H., Zhang, S., Peng, Y., Li, Y., Chen, Z., Xu, H., et al. (2015). Effects of marine actinomycete on the removal of a toxicity alga Phaeocystis globose in eutrophication waters. Front. Microbiol. 6, 474-484. doi: 10.3389/fmicb.2015. 00474

Zhang, T. T., Zheng, C. Y., Hu, W., Xu, W. W., and Wang, H. F. (2010). The allelopathy and allelopathic mechanism of phenolic acids on toxic Microcystis aeruginosa. J. Appl. Phycol. 22, 71-77. doi: 10.1007/s10811-0099429-6

Zheng, X., Zhang, B., Zhang, J., Huang, L., Lin, J., Li, X., et al. (2012). A marine algicidal actinomycete and its active substance against the harmful algal bloom species Phaeocystis globosa. Appl. Microbiol. Biot. 97, 9207-9215. doi: 10.1007/ s00253-012-4617-8

Zong, W. X., Ditsworth, D., Bauer, D. E., Wang, Z. Q., and Thompson, C. B. (2004). Alkylating DNA damage stimulates a regulated form of necrotic cell death. Gene Dev. 18, 1272-1282. doi: 10.1101/gad.1199904

Conflict of Interest Statement: The authors declare that the research was conducted in the absence of any commercial or financial relationships that could be construed as a potential conflict of interest.

The reviewer YB and handling Editor declared their shared affiliation, and the handling Editor states that the process nevertheless met the standards of a fair and objective review.

Copyright $\odot 2017$ Zhang, Wang, Zheng, Yao, Peng, Zhang, Hu, Tao and Zheng. This is an open-access article distributed under the terms of the Creative Commons Attribution License (CC BY). The use, distribution or reproduction in other forums is permitted, provided the original author(s) or licensor are credited and that the original publication in this journal is cited, in accordance with accepted academic practice. No use, distribution or reproduction is permitted which does not comply with these terms. 